\title{
河岸近傍の流速とヒサシ状河岸形成の関係 RELATION OF FLOW VELOCITY AROUND RIVERBANK AND FORMATION OF OVERHANGING BANK
}

\author{
福岡捷二 $1 \cdot$ 渡邊明英 $2 \cdot$ 山縣 $\quad$ 聡 $3 \cdot$ 柏木幸則 4 \\ Shoji FUKUOKA, Akihide WATANABE, Satoshi YAMAGATA and Yukinori KASHIWAGI \\ 1 フェロー会員 Ph.D 工博 広島大学教授 工学部第四類(建設系)（干739 広島県東広島市鏡山 1-4-1） \\ 2 正会員 工博 広島大学助教授 工学部第四類(建設系). \\ 3 学生員 広島大学大学院 環境工学専攻 博士課程前期 \\ 4 正会員（株)建設環境研究所（干170-0013 豊島区東池袋 2-23-2）
}

\begin{abstract}
There is a possibility of cohesive soil being used as a material of riverbank. For this purpose, it is important to investigate and estimate the erosive resistance of cohesive soils against the stream flow. Several studies on the erosion of cohesive soils have been made in recent years. In previous studies, the dynamic processes of bank erosion have been clarified. We have accumulated the knowledge about mechanism and process of erosion in cross and longitudinal directions. However, the knowledge is not sufficient in estimating the erosion amount and erosion speed.

The point of this paper is to examine the relation of flow velocity and erosion rate. Some hydraulic models were made to measure the flow velocity around eroded area in detail. One model reproduced faithfully the shape of erosion experiment to examine the longitudinal change in velocity, and another simplified the feature of overhanging bank to examine the effect of erosion angle. The important relations of flow characteristics and erosion mechanism are found as the consequence of those experiments.
\end{abstract}

Key Words : erosion mechanism, overhanging bank, longitudinal change of velocity, erosion angle

\section{1. 序論}

河岸には，治水機能だけでなく水際環境や景観に関す る機能も求められている.最近では, 自然河岸を保全した り,自然材料を用いて河岸保護工として利用する方法が考 えられている.しかし, そのためには, 河岸が流水に対し てどの程度まで耐えることができるのかを見積もってお く必要がある.

砂分等を多く含む土質材料で河岸が構成されていれば, 河岸の侵食抵抗はほとんど期待できない。しかし，粒径 の小さな粘土分を多く含む粘着性土であれば，流水に対 してある程度耐えることができることが示されている. このため, 粘着性土の耐侵食性を見積もることが緊急の 課題であり，わが国においても様々な研究が行われてい $3^{1,2), 3,4)}$.

福岡らは数年間にわたって，現地粘性土河岸の侵食機 構について検討を進めている.すなわち，現地高水敷上 に造られた水路の側岸侵食実験 ${ }^{2), 6)}$ や, 侵食過程に着目し
た実験 ${ }^{5), 6)}$, 現地高水敷から採取した土を用いた侵食実験 7),8)などである.これらの研究により，実際の粘着性河岸 材料の侵食が, 縦断·横断方向に拡大していく機構や, 河 岸近傍の流速が侵食拡大機構を決める主な要因となって いることが明らかにされてきた。 そこで本研究では，乱 さないで採取した吉野川高水敷土を用いた侵食実験 ${ }^{8)}$ の 結果をもとに, 河岸形状を再現した模型と侵食形状の特 徵を踏まえ単純化したヒサシ形状模型により，侵食構造 と河岸近傍の流速との関係を明らかにすることを目的と し，検討を行った。

\section{2. 粘性土河岸のヒサシ状侵食拡大機構}

\section{（1）河岸形状の変化と河岸近傍流速}

吉野川高水敷土の侵食実験 ${ }^{8}$ について簡単に説明する. 用いた試料は，長さ $4 \mathrm{~m}$ ，高さ $0.3 \mathrm{~m}$ ，奥行き $0.15 \mathrm{~m}$ である. この試料は, 比較的粘土分, シルト分を多く含み, 試料 全体の土質構造に偏りがない.ランダムに発生した侵食 
表-1 侵食実験条件，模型実験条件

\begin{tabular}{|c|c|c|c|c|}
\hline $\begin{array}{c}\text { 流量 } \\
(\mathrm{l} / \mathrm{s})\end{array}$ & $\begin{array}{c}\text { 平均流速 } \\
(\mathrm{cm} / \mathrm{s})\end{array}$ & $\begin{array}{c}\text { 平均水深 } \\
(\mathrm{cm})\end{array}$ & 水路公配 & $\begin{array}{c}\text { 平均 } \\
\text { 㑐ト数 }\end{array}$ \\
\hline 42.5 & 113.9 & 14.9 & $1 / 200$ & 0.94 \\
\hline
\end{tabular}

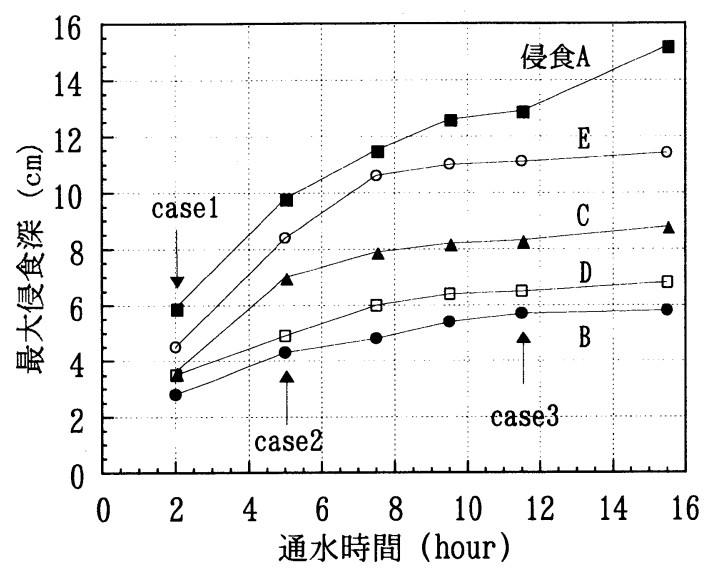

図-1 最大侵食深の経時変化

箇所が，表-1 に示す水理条件の流れによって，縦横断方 向に拡大する. 最大侵食深の経時変化を図-1 に示す.こ こでは，土の侵食されやすい部分で発生した深く掘れた 侵食箇所は，主に上流方向に拡大していき，逆に，浅く 平面的に侵食された箇所は下流方向に拡大していくとい うこと，また河岸侵食には，水面で生じるタイプと，水 面下の水路床付近で生じるタイプの二つが存在すること も分かった ${ }^{8)}$.

上述の侵食実験で明らかにされた河岸侵食の拡大機構 を，河岸近傍の流速との関係で説明するために，次のよ うな模型を用いた実験を行った．河岸模型は，大きく侵 食された $2 \mathrm{~m}$ 区間を，油粘土により再現している. 図-1 に示した侵食規模の経時変化において, 通水 2 時間, 5 時間, 11.5 時間の河岸形状を再現した。それぞれの模型 を用いた実験を case1, case2, case3 と呼ぶことにする. 模型の諸元は図-2 に示すように，侵食実験の形状と同じ であり，水理条件も，表-1に示した侵食実験の条件と全 く同様である. 模型の上下流には平板を設置し水路全長 にわたって水路幅を $0.25 \mathrm{~m}$ に設定している. 流速は, 電 磁流速計により模型河岸から $1.5 \mathrm{~cm}$ 離れた面において縦 断的に測定した.

図-3に, case1 の模型侵食深のコンターと模型表面で の近傍流速の縦断的な変化を示す.各侵食筒所を侵食 A,

B , C, D とする. 侵食 A と C が比較的深く掘れた侵食箇所 で, B とD が浅い侵食箇所である. 近傍流速は, 水路床か らの高さによらず同様の傾向を示しており, 侵食 A の直 下流では流れの剥離によって流速は大きく低下している. 流下に従い流速は徐々に回復し, 侵食 B に到達する.こ こでは，侵食形状が浅く平面的なため流速は低下せず, さらに加速している.

ここで, 河岸侵食を支配している要因について考える. 直立した河岸の侵食は, 河床変動とは異なり侵食された

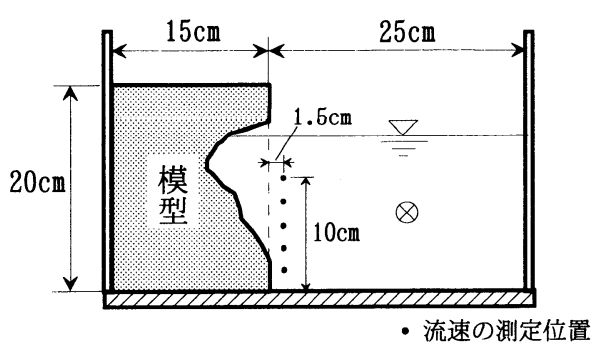

図-2 模型横断形状と流速測定点
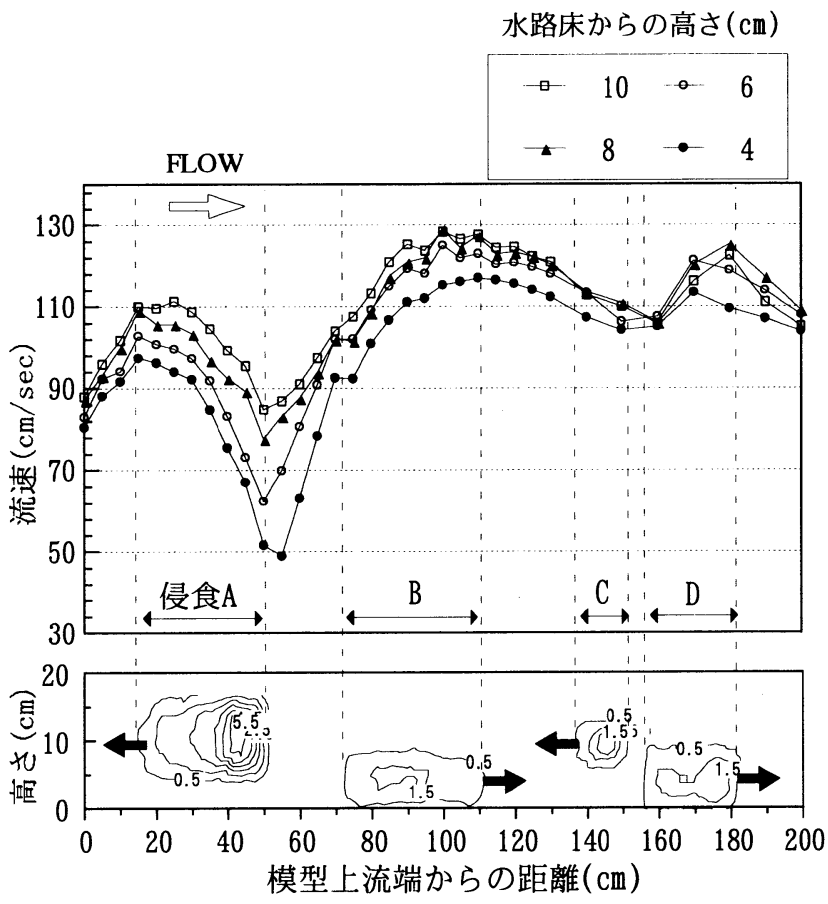

$\rightarrow$ 矢印は侵食の主な拡大方向

図-3＼cjkstart模型侵食深コンターと近傍流速の緃断分布 （case1，通水 2 時間）

土砂はすぐに流され，再び河岸に堆積することはない。 このため, 土の耐侵食性が同じであれば, 河岸近傍の流 速が大きいほど侵食されやすい. よって, 河岸近傍の流 速の絶対値が, 河岸侵食の重要な要素と言うことができ る ${ }^{1)}$. 先の侵食実験により得られた侵食面の上下流への拡 大機構を実験結果から説明する. 侵食 A，C は，上流側の 流速が下流側に比べて大きいため，主に上流方向に拡大 した. 逆に B，D は下流側の流速が大きいため，主に下流 側に拡大したと説明できる。

次に，侵食の進行速度が小さくなり，ほぼ安定状態に なった侵食形状を再現した case3 の結果を図-4に示す. 安定状態においても，流速分布の傾向は鉛直方法に変化 せず, case1 と同様, 侵食 $\mathrm{A}$ 直下流での流速が低下してい る. ところが, 大きな流速を持っていた侵食 B，D の区間 では, case1 からの流速の大きな低下が見られる.これは， 侵食が横断方向に進行し, 断面積が増加したためである. このように河岸近傍の流速が低下したため，河岸侵食の 進行速度は小さくなり, 河岸は安定状態に入ったと説明 できる. 


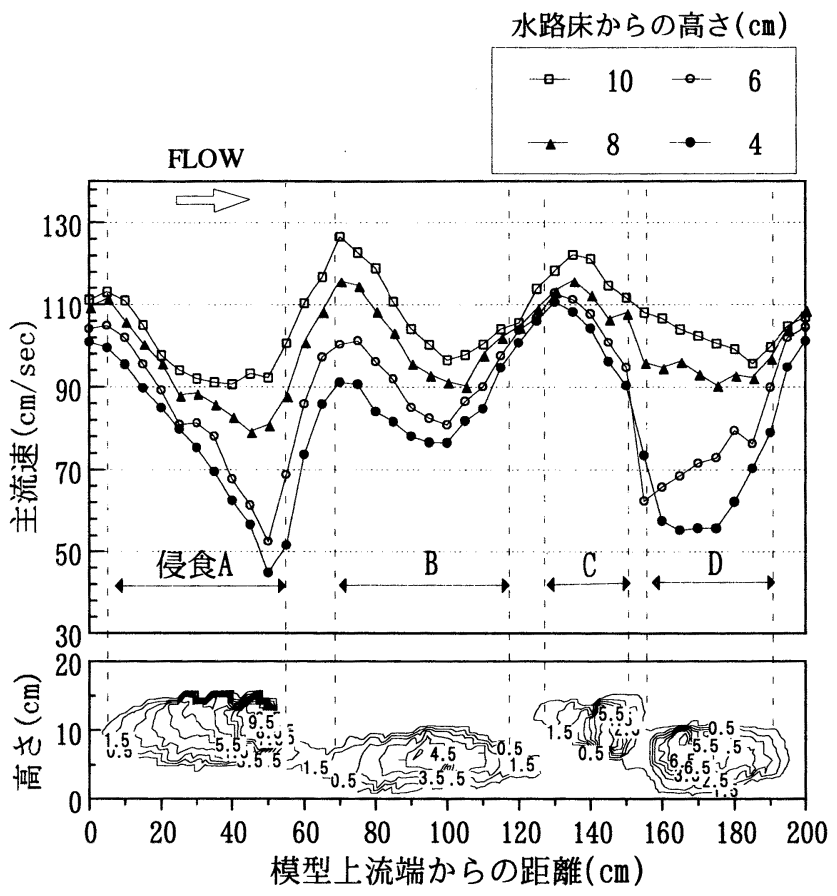

図-4模型侵食深コンターと近傍流速の縦断分布(case3)
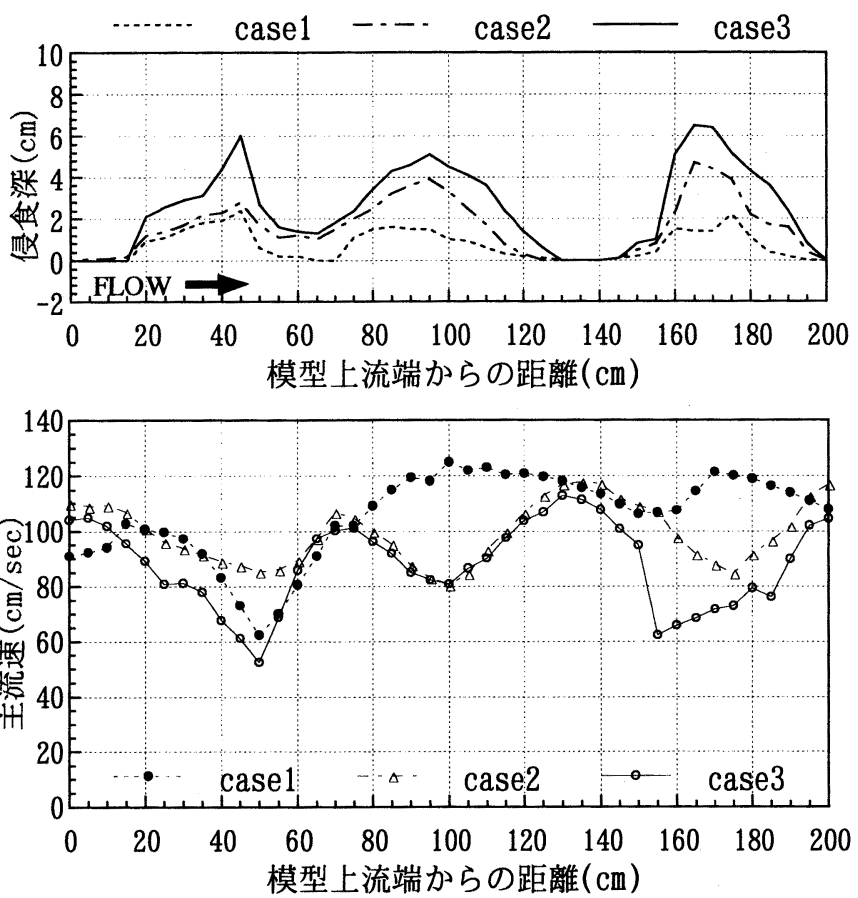

図-5 模型形状と主流速分布の比較(水路床から $6 \mathrm{~cm}$ )

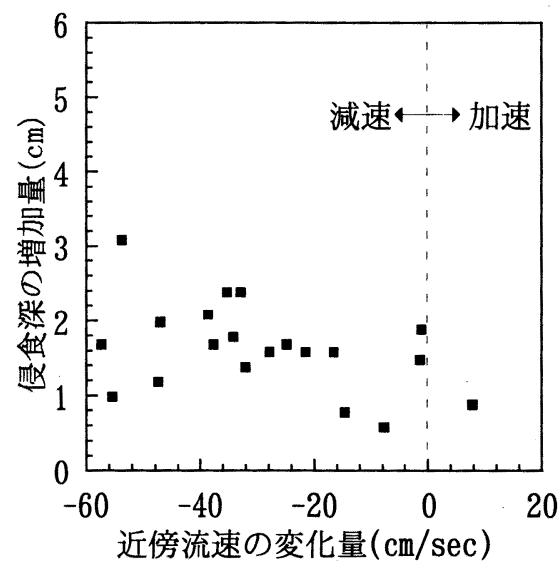

(a) 水路から $4 \mathrm{~cm}$

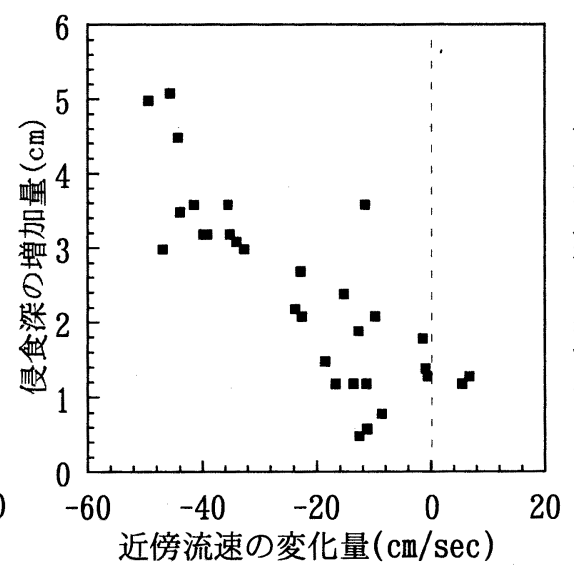

(b) 水路から $6 \mathrm{~cm}$

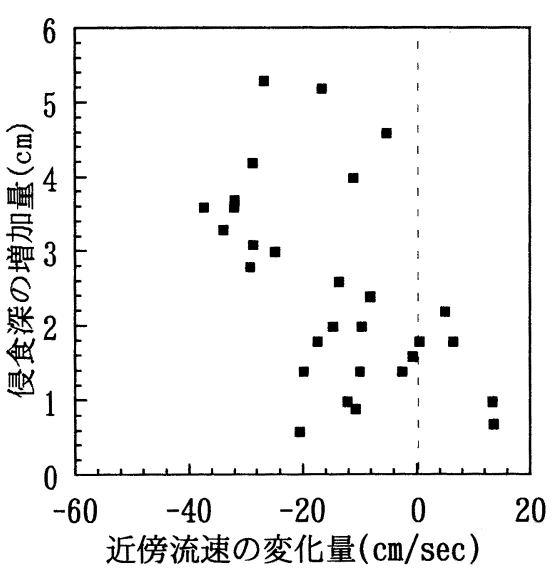

(c) 水路から $8 \mathrm{~cm}$

図-6 近傍流速の減少量と侵食深の増加量の関係( case1 から case3)

河岸形状の変化と近傍流速の関係について, 水路床か ら $6 \mathrm{~cm}$ の高さに着目し, さらに詳細に検討する. 図-5は, case1, case2, case3 の河岸の縦断形状と主流速の縦断分 布をそれぞれ示している.主流速の值は case1 から case3 までに, 最も大きい籄所で $50 \mathrm{~cm} / \mathrm{sec}$ 近く低下している. このような大きく減速している箇所で侵食深が同様に大 きく墚くなっており，これらの変化が対応しているよう に見える.

そこで, case1 から case3 に変化した時の, 各点での 近傍流速の減少量と侵食深の増加量の関係を, 水路床か ら $4 \mathrm{~cm}, 6 \mathrm{~cm}, 8 \mathrm{~cm}$ それぞれについて図-6に示す. 横軸に おいて負の值は近傍流速が低下していることを意味して いる. 近傍流速の減少量と侵食深の増加量の間には明ら かな相関が見られる. 水路床から $6 \mathrm{~cm}$ においては, 近傍 流速が大きく減少している籄所の侵食深が増加している. しかし, 水路床から $4 \mathrm{~cm}$ では, 流速が減少しているにも
関わらず，侵食深はあまり増加していない，逆に，水路 床から $8 \mathrm{~cm}$ では, 流速の変化が小さくても侵食深が増加 している.この理由は水面付近の方が流速は河床付近に 比べて大きく，侵食が進行しやすいためと考えられる. このように, 粘性土河岸の侵食拡大には, 侵食面近傍流 速の大きさと，侵食による流速減少量が重要な要素であ ることが示される.

ここまでの検討では, 侵食初期の case1 から最終的な 侵食安定状態の case3 への変化過程に着目している. し かし，その途中の遷移状態の case2 における，侵食・流 速関係を明らかにする必要がある. 図-5 のそれぞれの流 速分布を比較した図を見ると, 縦断距離 $50 \mathrm{~cm}$ 付近では, 他の case より流速が大きくなっている.これは侵食部の 上下流で侵食が進行し，流れやすくなったためと考えら れる. また, $100 \mathrm{~cm}$ 付近では, case2 と case 3 がほとんど 同様の分布を示している.このことは, 侵食深がある值 
以上に深くなっても河岸近傍流速には影響がないことを 示している.

以上のことから分かるように, case2 については, 先の 図-6に示したような相関は見られない。この問題は，流 況は侵食箇所を含む上下流との関係で決まるにも関わら ず，一点での流速と侵食拡大量にだけ着目していること から生じていると考えられる．また，侵食箇所は縦断方 向に異なる高さで存在しており, 同一高さの平面で検討 することにも多少の無理がある．しかし，侵食安定状態 にあるヒサシ状河岸の近傍流速変化量と侵食拡大量が密 接な関係にあることはこれまでの検討から疑いのないと ころである.

また，この関係は，侵食される前と侵食された後での それぞれの変化量の関係を示しているため, 両者の関係 を用いて侵食量の予測を行うことは困難なようである. 河岸侵食は点で生じるものではなく，侵食箇所一帯が面 的に侵食されて拡大する.これはある面が横断方向に後 退して面全体の侵食が進行していると考えることもでき る.よって侵食量を予測するには，侵食の進行を面的に とらえることも必要と考えられる.

\section{（2）安定したヒサシ状河岸と河岸近傍流速}

図-7は, 先に行われた吉野川侵食実験 ${ }^{8)}$ の結果であり， ある一つの侵食箇所について通水時間ごとの縦断形状を 示している. 侵食最深部に向かうラインが次第に急にな っている様子が見て取れる.これより考えられる侵食過 程は，土質的に侵食されやすい箇所が深掘れを形成しつ つ，上下流の侵食面の傾斜が増していくというものであ る. 図-8は，上述の侵食部の最深部へと向かう勾配(以下 侵食面角度とする)の経時変化を, 図-1に示した侵食箇所 A，B，Cについて示したものである. どの侵食箇所におい ても角度が増加しているが，次第に増加速度は小さくな り, 角度は $5^{\circ} \sim 9^{\circ}$ で安定している. このように粘性土 のヒサシ状河岸の侵食面角度が $5^{\circ} \sim 9^{\circ}$ で安定する機構 を理解することが河岸侵食解明の基本である.

このため次のような実験を行う. 実験で用いた模型の 概略を図-9 に示す．侵食部の規模は，実際の侵食規模と 同程度とし，侵食形状の特徵を単純化したヒサシ形状で ある. 模型は，侵食面角度を変え侵食深を大きくするこ とができる，ヒサシ上部には，電磁流速計プローブを差 し込むことのできる測定穴を設けた. 実験条件を表-2に 示す. 侵食面角度 $4^{\circ}, 6^{\circ}, 8^{\circ}$ の 3 パターンの形状と， 2 ケースの水理条件により実験を行った。流速の縦断分布 の検討に用いた測定点は, 図-10に示すように, 水路左岸 から $1 \mathrm{~cm}$ 離れた直線上と，ヒサシ内部の同じく壁面に沿 った線上での, 水路床から $5 \mathrm{~cm}, 7 \mathrm{~cm}, 9 \mathrm{~cm}$ の点である. 河岸侵食には水面付近で生じる夕イプと水面下で生じる タイプがあるが，本実験の模型と水理条件は，水面下で 河岸侵食が生じる夕イプに相当している．もう一方の水 面付近で生じるタイプについては，現在検討していると
表-2 模型実験条件

\begin{tabular}{|c|c|c|c|c|c|}
\hline & $\begin{array}{c}\text { 流量 } \\
(1 / \mathrm{s})\end{array}$ & $\begin{array}{c}\text { 水路勾 } \\
\text { 配 }\end{array}$ & $\begin{array}{c}\text { 平均流速 } \\
(\mathrm{cm} / \mathrm{s})\end{array}$ & $\begin{array}{c}\text { 平均 } \\
\text { 7川トード数 }\end{array}$ & $\begin{array}{c}\text { 侵食面角 } \\
\text { 度 }\left({ }^{\circ}\right)\end{array}$ \\
\hline caseA & 40.0 & $1 / 200$ & 111.4 & 0.96 & $4,6,8$ \\
\hline caseB & 30.0 & $1 / 400$ & 79.1 & 0.65 & 4,8 \\
\hline
\end{tabular}

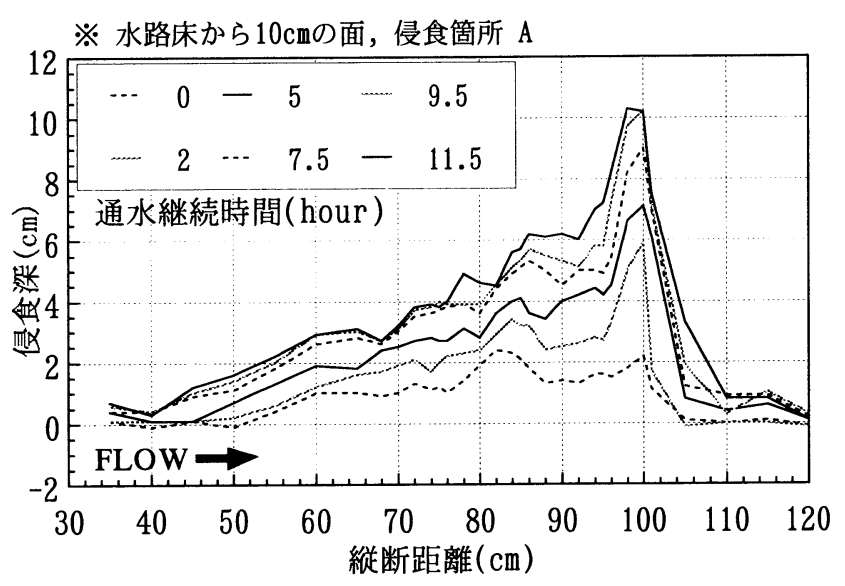

図-7吉野川侵食実験における侵食縦断形状

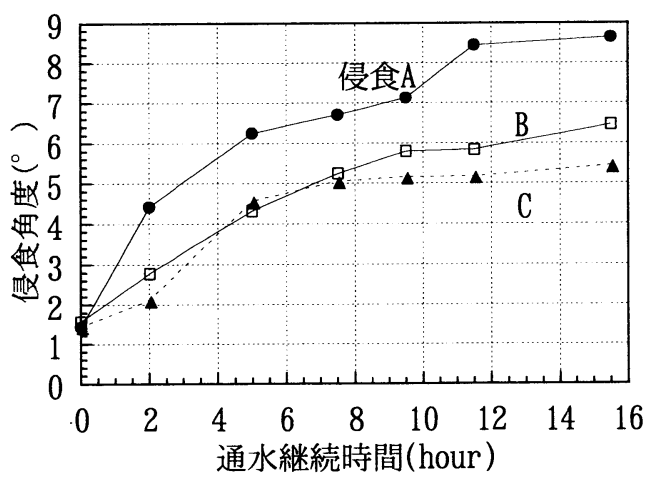

図-8吉野川試料における侵食面角度の経時変化

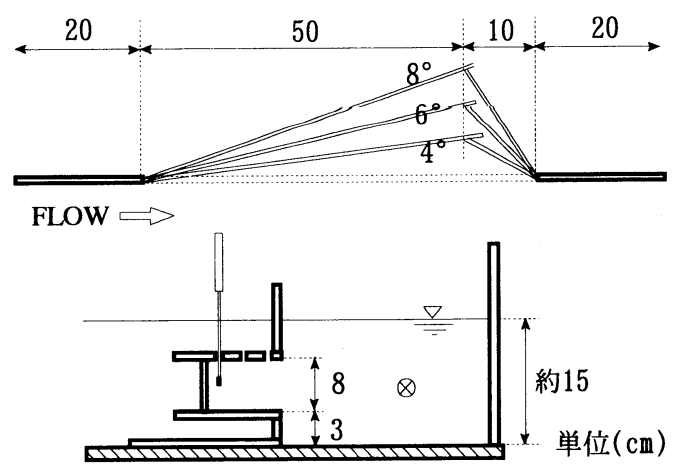

図-9傾斜侵食面を有する実験水路

\section{ころである。}

図-11 は, caseA,B の水深とフルード数の縦断分布を角 度ごとに示している. caseAでは, どの角度においても侵 食部による水路断面積の増加によって, 流速が低下し水 深は徐々に増加している. 模型の上流では, フルード数 が 1.2 と射流であったが，跳水を起こし常流に遷移して いる. 一方 caseB では, 水深のフルード数の増減は小さ く，流れは水路全体で常流である. 

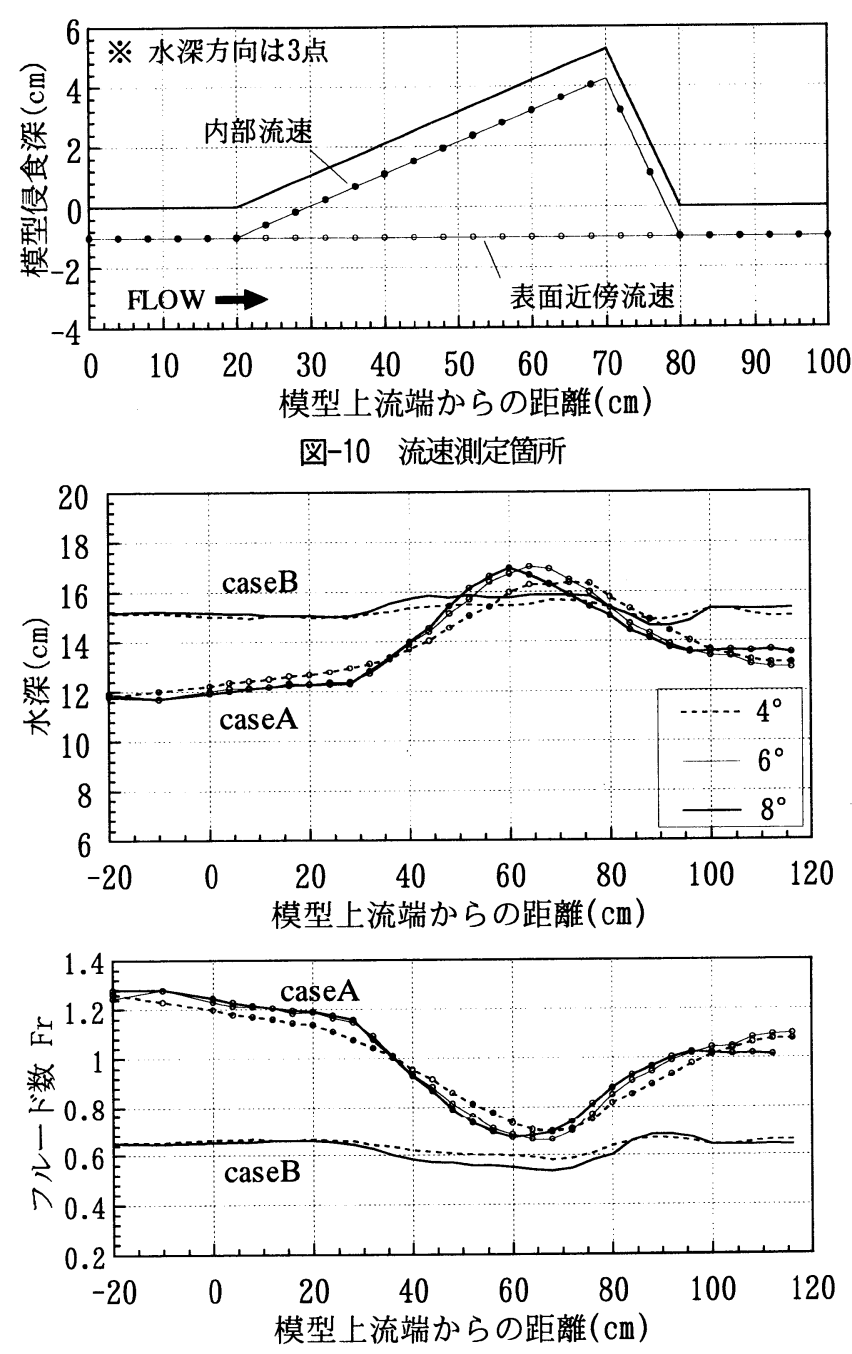

図-11 水深, フルード数の縦断分布

図-12 は, caseA における侵食面角度 $4^{\circ}$ と $8^{\circ}$ での, 水路床から $5 \mathrm{~cm}$ の平面における流速べクトルである. ヒ サシ内部の流速べクトルは傾斜面にほぼ沿って流れてお り，模型上流から流入し下流から流出している. しかし， 侵食面角度 $8^{\circ}$ の最深部では流速がほとんどなくなって いる.これは，流れが剥離しているためと考えられ，染 料により瞬間的な逆流が確認されている.一方 $4^{\circ}$ では依 然速い流速を保ち，流れの剥離は見られない。ヒサシ内 部では，このように傾斜面の大きさによって流況に違い が見られるが，ヒサシの外部では流況に大きな違いは見 られない。

ここで，流速の絶対值やその縦断分布を詳しく比較す る. 図-13に, caseAにおける水深方向に平均した流速の 縱断分布を示す. (a)の内部近傍流速は, 侵食部の始まる 位置である $20 \mathrm{~cm}$ 付近から低下し始め, 最深部の $70 \mathrm{~cm}$ の 辺りまで減速している. 侵食面角度によって流速の低下 量に大きな違いがあり，角度が急になるほど流速の低下 量は大きくなっている. ところが, (b)の表面近傍流速に ついては，模型上下流側では侵食面角度による違いが認 められるものの, 侵食深が増加している $20 \mathrm{~cm}$ から $70 \mathrm{~cm}$ の区間ではすべての侵食面角度でほとんど同一の值を示 している.この原因は, 角度が急になり水路断面積が増

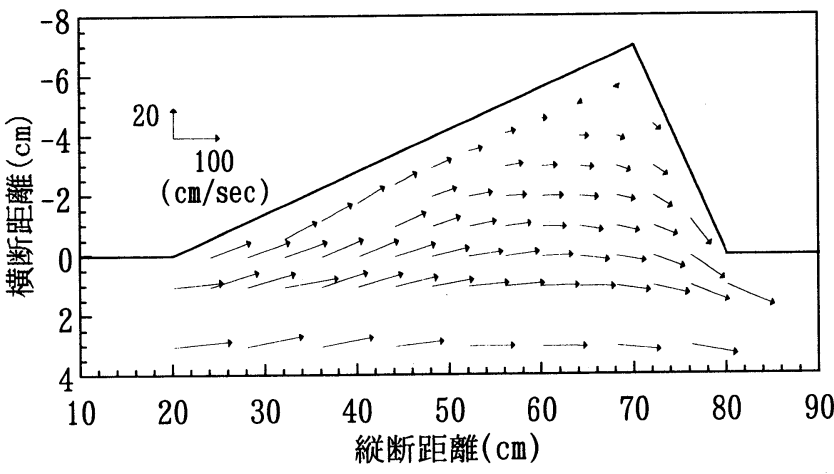

侵食面角度 $8^{\circ}$

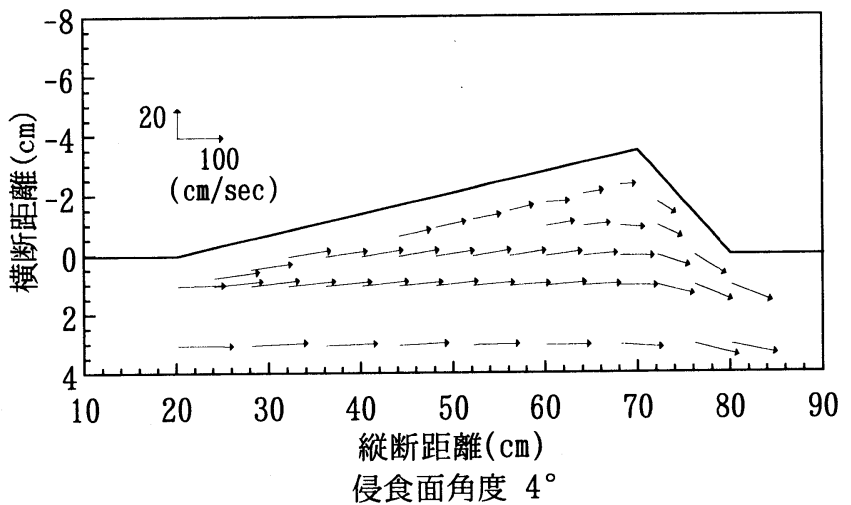

図-12 流速べクトル(水路床から $5 \mathrm{~cm}$ の面)

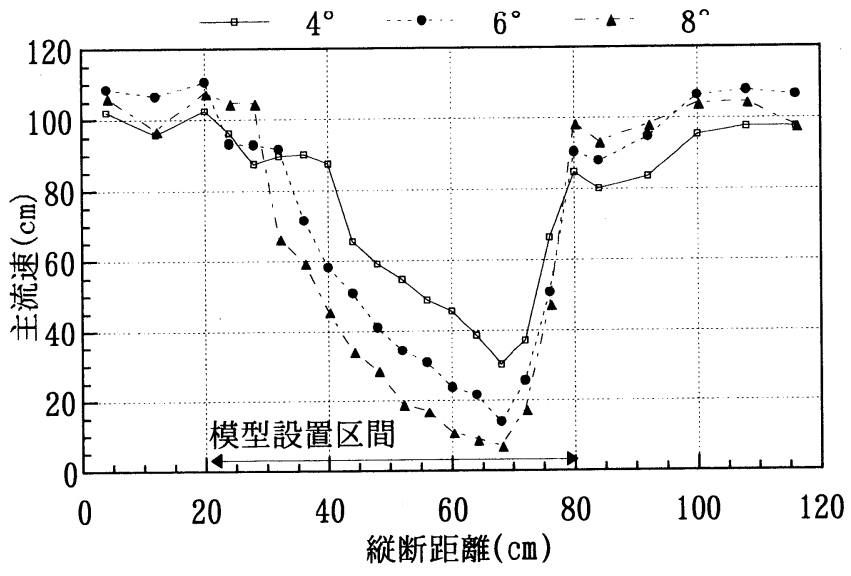

（a）ヒサシ内部流速

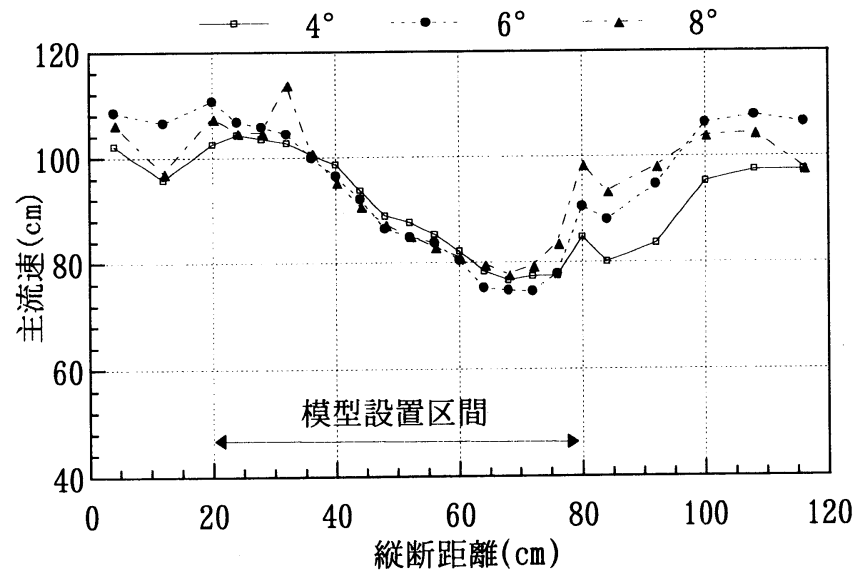

(b) 表面近傍流速

図-13 近傍流速の縦断分布（caseA） 
加しても, ヒサシ内部では流れの剥離により, 有効な断 面積が実際の断面積より小さくなったことや，模型上流 からの流れが射流であるため, ヒサシ外部の表面近傍流 速が, 形状の影響を受ける前に流下してしまったことが 挙げられる. また, 模型下流端の $80 \mathrm{~cm}$ 付近で流速が急激 に上昇している原因は, 模型下流端が角張った形状をし ているためと思われる.

図-14 は, caseB の結果を示している. それぞれの傾向 は caseA と同様であるが, (d)の表面近傍流速においては, $4^{\circ}$ から $8^{\circ}$ に傾斜面角度が変わると流速が減少しており, その減少量は約 $5 \mathrm{~cm} / \mathrm{sec}$ で, 絶対值の 1 割近くである. この時に(c)の内部流速は $4^{\circ}$ から $8^{\circ}$ で，さらに大きく 減少しており，概ね絶対値の 3 割の減少である.

caseA, B 共に内部流速は，侵食面角度の増加とともに低 下している. $8^{\circ}$ での流速は両者とも最も小さいところで $10 \mathrm{~cm} / \mathrm{sec}$ 程度まで低下している. 水理条件の違いにもか かわらず, 内部流速が $8^{\circ}$ で非常に小さくなっており, ヒ サシ内部ではこれ以上の侵食は起こらないと考えられる。 図-8で示したように，吉野川高水敷土を用いた侵食実験 においても, 侵食面角度は $5^{\circ} \sim 9^{\circ}$ で安定しており，土 質材料の不均一性や，侵食箇所の上下流が流れに与える 影響を考慮しても，侵食面角度はやはり $8^{\circ}$ 付近で安定す ると考えられる. また, caseB においては, 侵食面角度が $4^{\circ}$ から $8^{\circ}$ へ変化すると, ヒサシ内部の流況だけでなく, ヒサシの外部での流況も変化することが明らかとなった。

自然河岸においては，土質構造の場所的な違いが侵食 機構を決めていることがこれまでの現地調查により明ら かにされてきた ${ }^{3), 7)}$. 本研究では特別な土質構造を持たな い, ほぼ均質な粘性土の河岸侵食の拡大機構を検討して いる. 特別な土質構造を持たなければ，鉛直スケールの 異なる河岸においてもここで述べたと同様なメカニズム で侵食が拡大することが観測されている ${ }^{3)}$. しかし，本研 究で検討した模型構造は一定の形と大きさを持つ侵食形 状としているが, この形状が大きくなると侵食内部での 流況が変わることも予想される. また，ヒサシ部に対す る水面の位置によっても流況は変化することも考えられ る.このため, ヒサシ部の形状や水深も重要な要素であ り, 今後はこれらの面からの検討が必要である.

\section{3. 結論}

ヒサシ状河岸近傍の流況を様々な模型を用いて把握し， 河岸近傍流速と侵食拡大機構, 安定なヒサシ状河岸との 関係を検討した. 主要な結論を以下に示す。

1）河岸近傍流速の上下流での絶対值の差が, 河岸侵食の 上下流への拡大速度の違いを生じている.

2) 侵食が進行していない状態から, 侵食の進行が安定し た状態への河岸近傍流速の変化量と, 侵食拡大量との 間には強い相関がある。

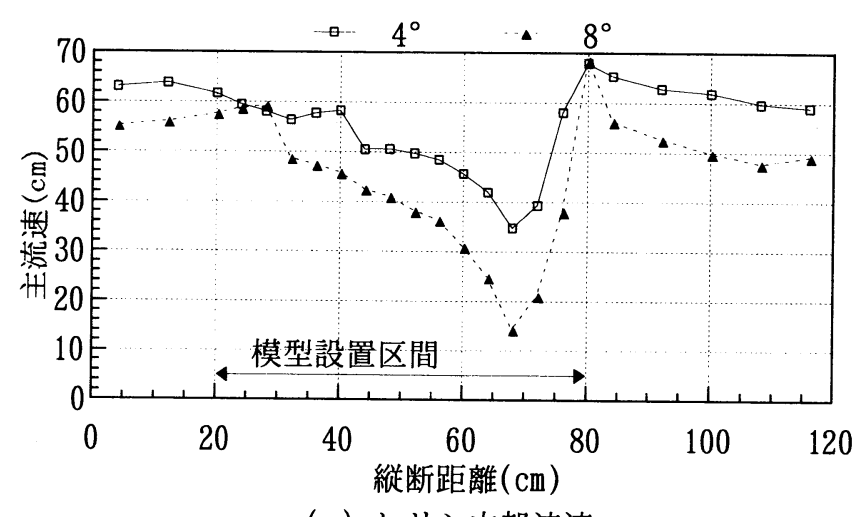

（c）ヒサシ内部流速

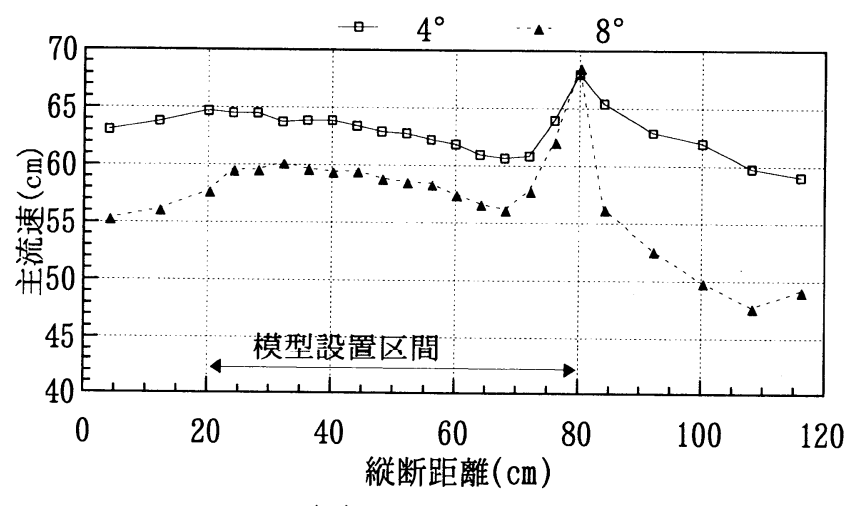

(d) 表面近傍流速

図-14 近傍流速の縦断分布 (caseB)

3) 侵食部が水面下にある場合, 侵食面角度の増加に伴い ヒサシ内部の流速は低下し, 侵食面角度は $8^{\circ}$ 付近で 安定する.

\section{参考文献}

1) Hasegawa, $K$ : Universal bank erosion coefficient for meandering rivers, J.Hydr.Engrg, ASCE,Vol.115,No.6,pp.744-765,1989.

2)福岡捷二, 木暮陽一, 佐藤健二, 大東道郎 : 自然堆積河岸の 侵食過程, 水工学論文集, 第 37 巻, pp.643-648, 1994.

3)建設省荒川上流工事事務所, 東京工業大学土木教室福岡研究 室: 河岸侵食·拡幅機構に関する研究, 94p., 1994.

4)建設省土木研究所 : 洪水流を受けた時の多自然型河岸防御 工・粘性土・植生の挙動 - 流水に対する安定性・耐侵食性を 判断するために一，土木研究所資料，第 3489 号，1997.

5)大東道郎, 福岡捷二, 佐藤健二 : 自然堆積河岸の侵食係数に ついて, 土木学会第 48 回年次学術講演会講演概要集, II, pp.568-569, 1993.

6)福岡捷二, 石川 浩, 日比野忠史, 島本重寿: 粘着性(ガ夕土) 流路の侵食, 流送過程に関する研究, 水工学論文集, 第 40 巻, pp.965-970, 1996.

7)福岡捷二, 渡邉明英, 小俣 篤, 片山敏男, 島本重寿, 柏木 幸則 : 河岸侵食速度に及ぼす土質構造の影響, 水工学論文集, 第 42 巻, pp.1021-1026, 1998.

8)福岡捷二, 渡邊明英, 片山敏男, 板屋英治, 柏木幸則, 山縣 聡, 林 基樹 : 粘性土(シルト)河岸の流水による侵食拡大機構, 水工学論文集, 第 43 巻, pp.695-700, 1999.

(1999.9.30 受付) 